慶應義塾大学学術情報リポジトリ

Keio Associated Repository of Academic resouces

\begin{tabular}{|c|l|}
\hline Title & $\begin{array}{l}\text { The structures of diethylaminoethylated glucose and oligosaccharides derived from cationic } \\
\text { starch }\end{array}$ \\
\hline Sub Title & \\
\hline Author & $\begin{array}{l}\text { 城座, 映明(Shiroza, Teruaki) } \\
\text { 降旗, 一夫( Furihata, Kazuo) } \\
\text { 遠藤, 豊成( Endo, Toyoshige) } \\
\text { 瀬戸, 治男( Seto, Haruo) } \\
\text { 大岳, 望( Otake, Noboru) }\end{array}$ \\
\hline Publisher & 共立薬科大学 \\
\hline Publication year & 1982 \\
\hline Jtitle & $\begin{array}{l}\text { 共立薬科大学研究年報 (The annual report of the Kyoritsu College of } \\
\text { Pharmacy). No.27 (1982.),p.72-75 }\end{array}$ \\
\hline JaLC DOI & \\
\hline Abstract & \\
\hline Notes & 抄録 \\
\hline Genre & Technical Report \\
\hline URL & https://koara.lib.keio.ac.jp/xoonips/modules/xoonips/detail.php?koara_id=AN00062898-0000002 \\
\hline $7-0072$ \\
\hline
\end{tabular}

慶應義塾大学学術情報リポジトリ(KOARA)に掲載されているコンテンツの著作権は、それぞれの著作者、学会または出版社/発行者に帰属し、その権利は著作権法によって 保護されています。引用にあたっては、著作権法を遵守してご利用ください。

The copyrights of content available on the KeiO Associated Repository of Academic resources (KOARA) belong to the respective authors, academic societies, or publishers/issuers, and these rights are protected by the Japanese Copyright Act. When quoting the content, please follow the Japanese copyright act. 


\title{
The Structures of Diethylaminoethylated Glucose and Oligosac- charides Derived from Cationic Starch $\dagger$
}

\author{
Teruaki Shiroza*, Kazuo Furihata*, Toyoshige Endō, \\ Haruo SETo* and Noboru ŌTAKE*
}

The cationic starch prepared by alkylamination of starch is produced in large quantity for the paper making industry. However, it is not well characterized which of the $\mathrm{OH}$ groups of the glucose residue is substituted by the functional group. Therefore, we isolated diethylaminoethylated glucose (DEAE-glucose) from the hydrolyzate of cationic starch and examined its structure by means of NMR spectrometry.

To a suspension of corn starch $(100 \mathrm{~g})$ in $160 \mathrm{ml}$ of water was added $3.0 \mathrm{~g}$ of diethylaminoethylchloride at $\mathrm{pH} 10.5$, and the mixture was kept for 16 hours at $40^{\circ} \mathrm{C}$. After filtration of slurry at $\mathrm{pH} 5.0$, the filtered cake was washed with water and dried in hot air. The degree of substitution was determined as 0.025 by the Kjeldahl method.

The cationic starch was gelatinized with $1 \mathrm{~N} \mathrm{HCl}$ for $30 \mathrm{~min}$ at $100^{\circ} \mathrm{C}$ and further hydrolyzed completely for 72 hours at $70^{\circ} \mathrm{C}$. After being adjusted to $\mathrm{pH} 7.0$, the insoluble material was removed by centrifugation and the supernatant applied to a column of Dowex $50 \mathrm{~W}-\mathrm{X} 2\left(\mathrm{H}^{+}\right.$form). The column was washed with water, then eluted with $0.5 \mathrm{M} \mathrm{NH}_{4} \mathrm{OH}$ and the eluate was evaporated in vacuo to yield a crude fraction.

The silics gel TLC $\left(\mathrm{CHCl}_{3}-\mathrm{MeOH}-\right.$ conc. $\left.\mathrm{NH}_{3} 2: 3: 1\right)$ of the crude fraction gave two components, a main spot at $R f 0.77$ and a minor one at $R f 0.66$. In agreement with this, the ${ }^{13} \mathrm{C}-\mathrm{NMR}$ spectrum of the crude fraction (in $\mathrm{D}_{2} \mathrm{O}$ ) showed 16 carbon signals as well as some very weak signals. Of the former signals, 12 were assignable to a pair of $\alpha, \beta$-anomers of the glucose residue. These findings suggest that substitution occurred mainly at the single $\mathrm{OH}$ group of glucose together with a slight side reaction at other $\mathrm{OH}$ groups. The crude fraction was further purified by Dowex $50 \mathrm{~W}-\mathrm{X} 2$ column chromatography using a $0.5 \mathrm{~m}$ pyridine-AcOH buffer, $\mathrm{pH}$ 6.4. The eluate was monitored by TLC and appropriate fractions were combined to give purified DEAE-glucose ( $1, R f 0.77$ ).

In order to confirm the substitution pattern, 1 was peracetylated with acetic anhydride/pyridine to afford tetraacetyl DEAE-glucose, 2, (EI mass $\mathrm{M}^{+} 447.2029, \mathrm{C}_{20} \mathrm{H}_{33} \mathrm{NO}_{10}$ Calcd. 447.2102). In the $400 \mathrm{MHz}{ }^{1} \mathrm{H}-\mathrm{NMR}$ spectrum of 2 in $\mathrm{CDCl}_{3}$, the signals due to $\mathrm{H}-1 \beta, 3 \beta$ and $4 \beta$ were observed at $\delta 5.59,5.17$ and $5.02 \mathrm{ppm}$, respectively. On the other hand, the H-2 $\beta$ proton signal appeared at $\delta 3.47 \mathrm{ppm}$ which resonated at upper field than $\mathrm{H}-1 \beta, 3 \beta$ and $4 \beta$, clearly indicating that derivation took place at $\mathrm{C} 2-\mathrm{OH}$. This established the structures of 1 and 2 as shown below.

The assignment of the carbon signals for 1 could be made by calculation of the

$\dagger$ Agr. Biol. Chem. 46 (5) 1425 1427 (1982) 飞発表

* Institute of Applied Microbiology. The University of Tokyo. 
No. 27 (1982)
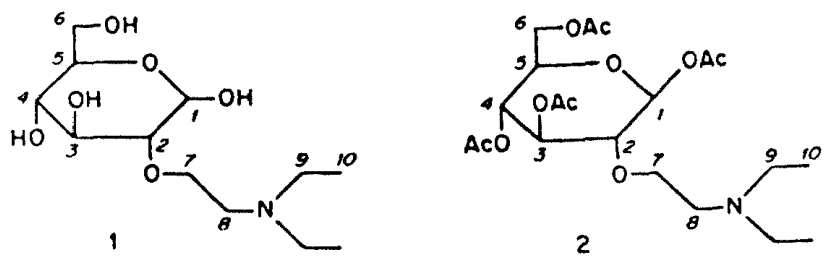

Table I. ${ }^{13} \mathrm{C}-\mathrm{NMR}$ Data of 1 and 2

\begin{tabular}{ccccccccccc}
\hline & 1 & 2 & 3 & 4 & 5 & 6 & 7 & 8 & 9 & 10 \\
\hline$\alpha$-Glucose & 95.10 & 75.75 & 74.35 & 72.05 & 74.35 & 63.55 & & & \\
& -2.2 & +9.5 & -2.2 & +0.9 & +0.7 & & & & & \\
$1-\alpha$ Calcd. & 92.90 & 85.25 & 72.15 & 72.95 & 75.05 & 63.55 & & & & \\
Obsd. & 92.16 & 81.97 & 73.75 & 72.16 & 74.58 & 63.03 & 65.94 & 54.04 & 49.87 & 10.52 \\
$\beta$-Glucose & 98.95 & 77.10 & 78.70 & 72.05 & 78.85 & 63.70 & & & & \\
$1-\beta$ Calcd. & -2.2 & +9.5 & -2.2 & +0.9 & +0.7 & & & & & \\
Obsd. & 98.13 & 86.60 & 76.50 & 72.95 & 79.55 & 63.70 & & & & \\
$2-\beta$ & 93.43 & 78.76 & 74.67 & 72.16 & 78.39 & 63.23 & 68.06 & 54.04 & 49.87 & 10.52 \\
$-\mathrm{CO}-$ & 170.43 & 169.82 & 169.56 & 168.73 & & & & & & \\
$-\mathrm{CH}$ & 20.86 & 20.65 & 20.57 & 20.49 & & & & & & 10.62 \\
\end{tabular}

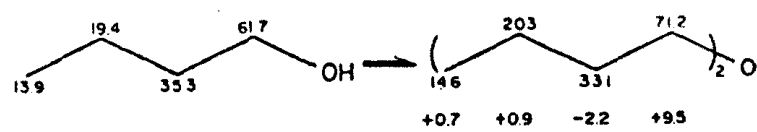

substituent effects on an aliphatic alcohol by bulky ether (see Table I). ${ }^{1)}$ In this case, $\mathrm{C}-2$, located at an $\alpha$-position of the ether bond, was shifted downfield by $9.5 \mathrm{ppm}$ and both $\mathrm{C}-1$ and $\mathrm{C}-3$, at $\beta$-positions, were shifted upfield by $2.2 \mathrm{ppm}$ from the parent sugar. All the carbon signals assigned to the glucose residue were well in accord with those of the calculated chemical shift. The ${ }^{13} \mathrm{C}-\mathrm{NMR}$ data of 2 (in $\mathrm{CDCl}_{3}$ ), assigned by a selective proton decoupling experiment, are also listed in Table I. The minor signals of crude DEAE-glucose were assigned as 3-O-DEAE and 6-O-DEAE derivatives in the same manner (data not shown). The minor spots on TLC ( $R f$ 0.66) might be attributed to these two derivatives.

Mild acid hydrolysis $\left(0.5 \mathrm{~N} \mathrm{HCl}, 70^{\circ} \mathrm{C}, 72\right.$ hours) of the cationic starch after gelatinization gave a DEAE-oligosaccharide mixture, together with DEAE-glucose, and these were separated by Dowex 50W-X2 column chromatography. The DEAE-maltose (TLC Rf 0.54) was peracetylated to give heptaacetyl DEAE-maltose, 3, (EI mass $\mathrm{M}^{+} 735, \mathrm{C}_{32} \mathrm{H}_{49} \mathrm{NO}_{18}$, Calcd. C 52.24, $\mathrm{H} 6.67, \mathrm{~N} 1.09 \%$, Obsd. C 52.32, $\mathrm{H} 6.71, \mathrm{~N} 1.93 \%$ ). In the ${ }^{1} \mathrm{H}-\mathrm{NMR}$ spectrum $\left(\mathrm{CDCl}_{3}\right)$, the signal resonating at $3.48 \mathrm{ppm}$ was assigned to $\mathrm{H}-2$ ' by its splitting pattern and coupling constants (dd, $10 \mathrm{~Hz}, 4 \mathrm{~Hz}$ ). This fact and the result of spin decoupling experiments afforded the structure for $\mathbf{3}$ as shown below.

In order to obtain some information about the action mechanism of amylases on 


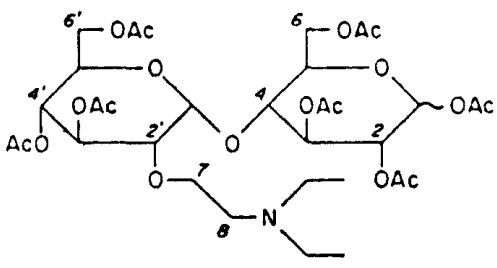

3
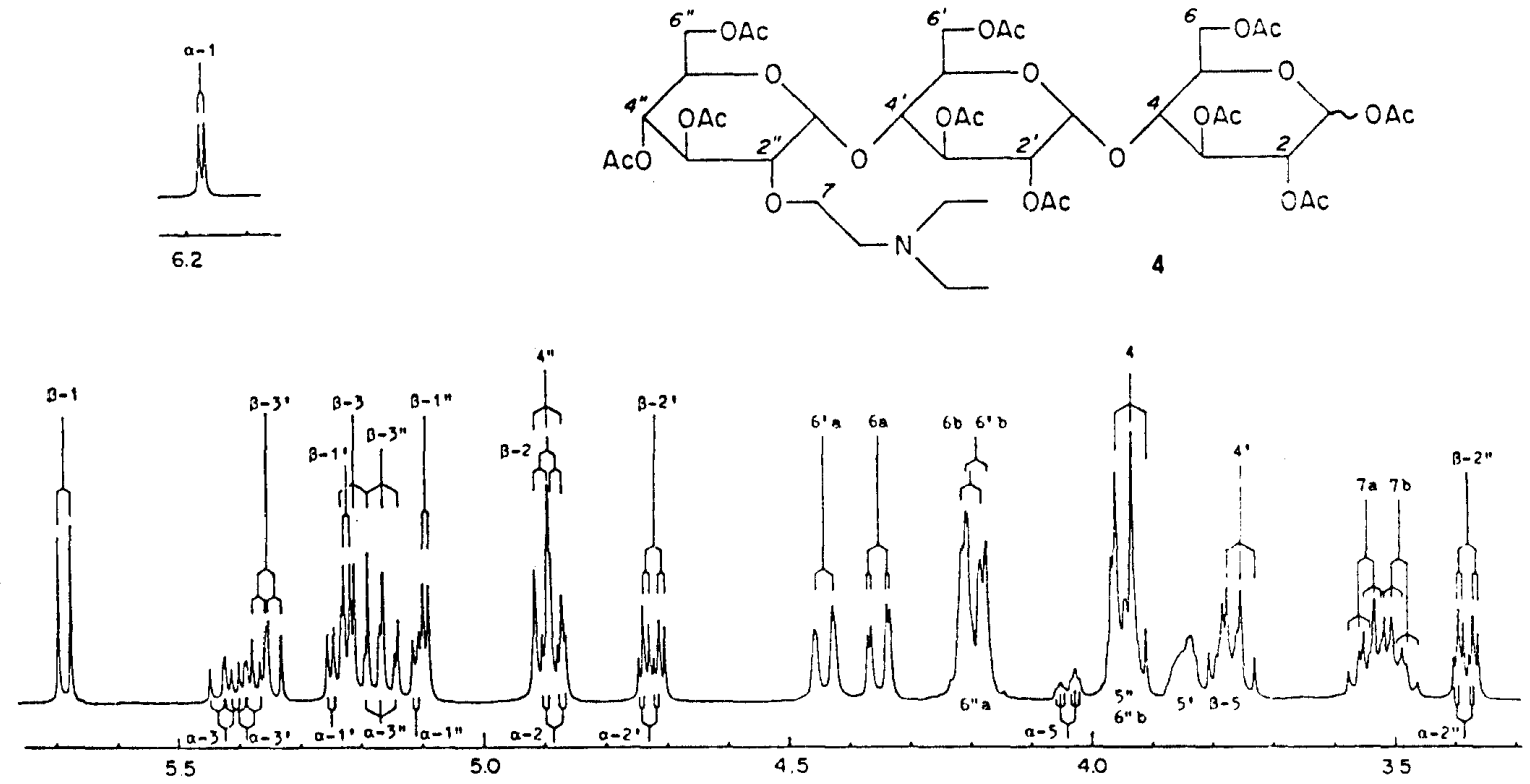

Fig. 1. ${ }^{1} \mathrm{H}-\mathrm{NMR}$ Spectrum of 4 in $\mathrm{CDCl}_{3}$.

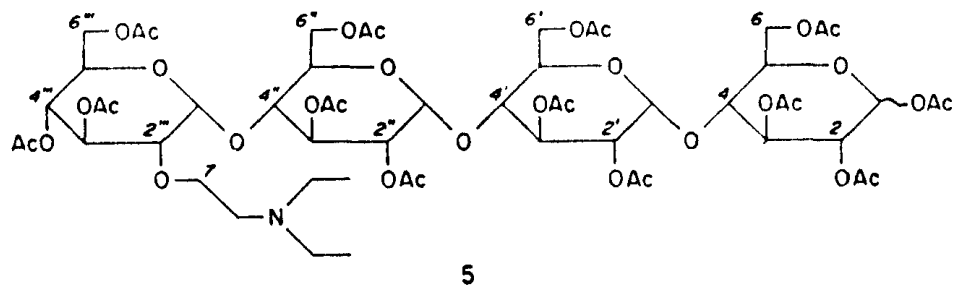

oligosaccharides having such a bulky substituent, cationic starch was subjected to hydrolysis using the combination of thermostable $\alpha$-and $\beta$-glucoamylases. The enzymatic hydrolyzate was purified by the same procedure described above. As a result, DEAEmaltotriose and DEAE-maltotetraose were mainly obtained, but no DEAE-maltose (TLC Rf 0.33 and 0.19 , respectively). Peracetylation of these DEAE-oligosaccharides gave peracetyl DEAE-maltotriose, 4, (EI mass $\mathrm{M}^{+} 1023, \mathrm{C}_{44} \mathrm{H}_{65} \mathrm{NO}_{28}$, Calcd. C 51.61, H 6.35, N 1.37\%. Obsd. C 51.20, $\mathrm{H}$ 6.16, $\mathrm{N} \mathrm{1.63 \% )} \mathrm{and} \mathrm{peracetyl} \mathrm{DEAE-maltotetraose,} \mathrm{5,} \mathrm{(EI} \mathrm{mass}$ $\mathrm{M}^{+} 1311, \mathrm{C}_{56} \mathrm{H}_{81} \mathrm{NO}_{34}$, Calcd. C 51.26, $\mathrm{H} 6.18, \mathrm{~N} 1.07 \%$, Obsd. C 51.20, H 6.16, N 1.00\%). ${ }^{1} \mathrm{H}-\mathrm{NMR}$ spectral analysis of 4 in $\mathrm{CDCl}_{3}$, including exhaustive spin decoupling and PRFT experiments, permitted us to assign all the signals and the structure was determined as shown in Fig. 1. The structure of $\mathbf{5}$ was also identified by the same NMR technique, 
although complete assignment was not successful. The oligosaccharide sequences of 4 and 5 were again confirmed by EI mass spectrometry (data not shown).

Based on these results, it could be concluded, that 1) $\alpha$-amylase could attack at the glucosidic linkages located at 3 or 4 glucose units away from the barrier in the direction of the reducing end and 2)glucoamylase hydrolyzed the glucosidic linkages of the resultant oligomers just before the alkylaminated glucose residue. Since the results of enzymatic degradation may depend on the origin of the enzymes used, it is suggested that some information concerning the action mechanism of amylases may easily be obtained by using the cationic starch as an enzyme substrate.

\section{Reference}

1) J.B. Stothers, "Carbon-13 NMR Spectroscopy," Academic Press, 1972. 